\title{
CAUSAL MAPS AND INDIRECT INFLUENCES ANALYSIS IN THE DIAGNOSIS OF SECOND-HOME TOURISM IMPACTS ${ }^{1}$
}

\author{
Hugo GARCÍA-ANDREU
}

Guadalupe ORTIZ

Antonio ALEDO

University of Alicante. Department of Sociology I. University Institute of Tourism Research. Hugo.andreu@ua.es; Guadalupe.ortiz@ua.es; Antonio.aledo@ua.es

\begin{abstract}
This paper proposes a method for diagnosing the impacts of second-home tourism and illustrates it for a Mediterranean Spanish destination. This method proposes the application of network analysis software to the analysis of causal maps in order to create a causal network model based on stakeholder-identified impacts. The main innovation is the analysis of indirect relations in causal maps for the identification of the most influential nodes in the model. The results show that the most influential nodes are of a political nature, which contradicts previous diagnoses identifying technical planning as the ultimate cause of problems.
\end{abstract}

Keywords: causality, network, UCINET, planning, modelling.

\section{INTRODUCTION}

The popularity of network analysis as an analytical framework has increased since the 1990s driving the social sciences forward at highly advanced levels of analysis and understanding of social reality (Scott and Carrington, 2011). Tourism studies have benefited, together with other fields of knowledge, from this approach and its tools. The recognition of tourism as a complex and interconnected system (Faulkner and Russell, 2003; Jamal y Getz, 1995) has turned it into an appropriate object of study for network analysis. This way of approaching tourism has given rise to a proliferation of research revealing the importance of recognising the interconnections between the multiple elements that take part in the tourism system. Diverse studies have applied the analysis of these interactions (among individuals, groups or organizations) to the understanding and improvement of governance and policy tourism networks, leadership, knowledge management, entrepreneurial cooperation and the development of tourism marketing strategies (Scott, Baggio y Cooper, 2008). With similar aims, network analysis has also been used in the form of Causal Network Methodology (CNM) for the specific identification of the sequence

${ }^{1}$ R\&D\&i project funded by the Ministry of Science and Education under the title Residential tourism: analysis of demand and proposals for restructuring consolidated destinations (SEJ/2005/04305). 
of causal relationships that link the elements of the tourism system. The most outstanding work in this line has been that of Nash (2006) and Woodside (2007). Nash uses CNM to identify the causal relationships among the main issues of concern to tourism providers in three peripheral Scottish destinations. With this application, Nash is able to highlight obstacles to effective tourism policy delivery of concern to the various public and private actors involved. Woodside (2007) uses CNM in the study of tourism psychology and behaviour in order to explain the decision-making process behind the selection of a particular destination. Among his conclusions this author suggests a line of research in which indirect influences are taken into account in order to better understand a causal network. This paper takes up Woodside's proposal and develops a method for analysing indirect influences in the causal network of the local impacts of tourism.

Indirect influences have been widely studied in the analysis of networks of actors using supporting software for network analysis (SSNA) such as UCINET, NetMiner, GRADAP, NEGOPY, and MultiNet. However, although supporting software has also been applied in CNM (Narayanan and Armstrong, 2005), as far as we know to date, there has been no significant work on the analysis of indirect influences in the case of the CNM. Since the SSNA and CNM have "common mathematical roots in graph theory" (Hodgkinson and Clarkson, 2005: 75), the elements which connect them should be studied. Several researchers have taken up this approach in the field of group decision making. For example, Ward and Reingen (1990) combined SSNA and CNM to study how social structure influences shared knowledge and how this influences consumer choice. Also, Weber and Manning (2001) applied UCINET to CNM in order to uncover patterns of internal consistency and conceptual similarity (clusters) in the context of school leadership. These tools have allowed us to make progress in social analysis from a systemic approach and observe behaviours and patterns in the social system which are not observable on a smaller, fragmented or individualized scale. In this way, one can combine the possibilities that CNM offers for visualising cause-effect structures with those offered by tools like UCINET. This means we can probe the nature of these structures more deeply, beyond the direct relationships between nodes in a network. Our research takes advantage of the UCINET software's power to systematically manage indirect relationships and identify which causes have the greatest influence in the causation of tourism impacts.

We have chosen the coastal municipality of Dénia as a case study to illustrate this methodological and analytical approach. This town is located on the northern stretch of the Costa Blanca, in the province of Alicante (Spain). Second-home tourism appeared with intensity in the 1960s in Dénia and its development has been accompanied by significant urban and demographic growth. Between the 1960s and the year 2011, 40,403 homes were built (Spanish National Statistics Institute, 2012). According to data from the most recent Spanish Population and Household Census, out of the total of existing homes in Dénia in 2011, 26,090 were second homes (60.2\% of the total), being $11,63 \%$ of them single family houses and the rest multi-family units. Although there is no data available for the case of Dénia, the results from research in similar tourism destinations show that vacation and economic investment characterize the usage pattern of these second homes in the Costa Blanca (Fernández, 2006: 27). Demographic growth has also accompanied tourist development in Dénia: the 12,185 inhabitants recorded in 1960 had doubled by 1991, and 20 years later they exceeded 44,000 (Spanish National Statistics Institute, 2012). This growth was due, on the one hand, to the intense labour immigration 
processes that started in the 60s. This immigration initially involved Spaniards from the centre and south of the country and, since 1999, foreign immigrants from Eastern Europe, Latin America and North Africa. The employment opportunities in the tourism and construction sectors explains the attraction of new population (Viruela and Domingo, 2001). On the other hand, the demographic growth is also explained by the retirement migrations processes from Western and Central Europe (García-Andreu and Rodes, 2004). During this period, traditional activities such as farming, fishing and the toy manufacturing industry were progressively abandoned in favour of the property sector and tourism-based services (Vera, 1992; Ciudad, 1995).

As a result, tourism in Dénia shows all the characteristics of a mature second-home destination: strong seasonality and high spatial concentration, spontaneous and dispersed urban development, little development of complementary tourism products, major environmental and landscape impacts and excessive dependence on the construction sector (Vera et al., 1990; Aledo and Mazón, 2005; Mazón, 2006). One of the features of mature destinations is that, in time, tourism comes to form an indissoluble part of local social processes. Since tourism is intertwined with local social structures and dynamics, its analysis must consider other variables not strictly linked to tourism. The causal networks analysis used in our research allows us to approach the analysis of tourism from this point of view, as we explain in the following paragraphs.

\section{METHOD}

The method adopted in this study uses CNM to describe the network of causal relationships at the root of the impacts deriving from second-home tourism development in Dénia. The causal map is the tool used for gathering, producing and displaying information. The building of these causal maps is based on information provided by local stakeholders. The content of the causal maps was subsequently analysed using UCINET software which allowed us to include indirect relationships in our analysis of causality in the network.

The method consists of three phases whose final objective is to analyse the causal maps of the principal local impacts caused by second-home tourism. In Table 1 below each of the phases are shown in summary form.

Table 1. Summary of method.

\section{Phases}




\begin{tabular}{|c|c|c|}
\hline $\begin{array}{l}\text { Identification of impacts derived } \\
\text { from second-home tourism in } \\
\text { Dénia }\end{array}$ & 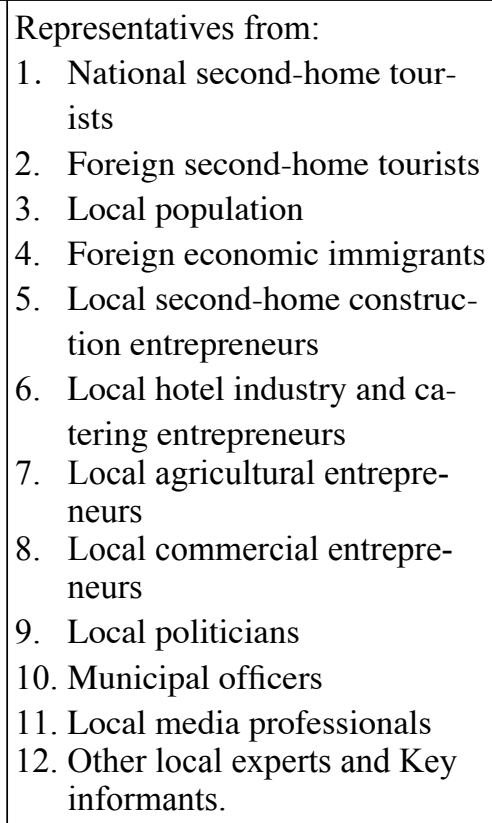 & $\begin{array}{l}\text { Individual interviews and focus } \\
\text { groups }\end{array}$ \\
\hline Production of causal maps & $\begin{array}{ll}\text { Representatives from: } \\
\text { 1. } & \text { National second-home tour- } \\
& \text { ists } \\
\text { 2. } & \text { Foreign second-home tourists } \\
\text { 3. } & \text { Local population } \\
\text { 4. } & \text { Foreign economic immigrants } \\
\text { 5. } & \text { Local entrepreneurs } \\
\text { 6. } & \text { Municipal officers } \\
\text { 7. } & \text { Local experts and Key infor- } \\
& \text { mants not linked to institu- } \\
\text { tions. }\end{array}$ & $\begin{array}{l}\text { Causal maps and deliberative } \\
\text { workshops }\end{array}$ \\
\hline Causal Maps Analysis & Researchers & $\begin{array}{l}\text { Network Analysis with Ucinet } \\
\text { and NetDraw }\end{array}$ \\
\hline
\end{tabular}

\section{Identification of impacts derived from second-home tourism in Dénia}

The objective of this phase was to identify the various impacts caused by second-home tourism in Dénia. To ensure a diversity of approaches and perspectives we consulted local stakeholders. In order to gather the largest possible number of views we consulted stakeholders who represented each one of the eleven theoretical categories into which, for the purposes of our research, we segmented the local community: national second-home tourists, foreign second-home tourists, local population, foreign labour immigrants, local second-home construction entrepreneurs, local hotel industry and catering entrepreneurs, local agricultural entrepreneurs, local commercial entrepreneurs, local politicians, municipal officers and local media professionals. These theoretical categories are taken from a literature review (Stroud, 1995; Munres, 1995; O'Reilly, 2000; Hall and Muller, 2004) and previous research into the region's secondhome tourism (García-Andreu and Rodes, 2004; Ortiz et al., 2007). As indicated by Valles, when 
discussing the issue of sampling decisions in qualitative research, the local community should be segmented into theoretical categories in order to "create an initial classification system similar to operations used to stratify and set survey sample quotas" (2003: 210). The creation of categories attempts to reduce local society's complexity and heterogeneity by constructing artificial groups based on shared elements (their similar structural position and experience with regard to second-home tourism). Of course this does not mean that the group of second-home users (national second-home tourists and foreign second-home tourists) share the same vision on the impacts of this type of tourism. Nonetheless, this vision will almost certainly be different from and complementary to that of the other stakeholders, such as the collective of foreign labour immigrants. Also the different position in the economic structure of the various local entrepreneurs (building, commerce, the catering and hotel industry, and agriculture) conditions their opinions on second-home tourism and its impacts. These opinions are different not only to those of other non-economic stakeholders but also among the entrepreneurs themselves (for example, the differences between second-home entrepreneurs and those in the hotel industry). It is also interesting to note the perception of impacts of local politicians and municipal officers, bearing in mind their position in the town council and their responsibilities over water supply, waste management, transport, town planning, etc.. Also, the nature of the media professionals' work makes them relevant to our research since they are nodes in the production and management of local information. Further local informants were chosen using the snowball technique, asking those interviewed to suggest other names. This new interviewees did not necessarily have to belong to their institutions, but they were selected because they might supply interesting information for identifying impacts. Thus, in the end we added a further category named "other local experts and key informants".

During the phase of identification of impacts derived from second-home tourism in Dénia, a total of 48 stakeholders took part. The impacts were identified using two techniques: focus groups and in-depth interviews. Focus groups were organised for each of the following categories: national second-home tourists, foreign second-home tourists, local population and foreign labour immigrants. In the case of local population the size of the category led us to form two focus groups: from the ages of 18 to 45 and from 46 upwards. This approach was used due to the heterogeneity of the collectives and the benefits of group interaction, such as the effects of synergy, stimulation and security (Morgan and Krueger, 1997). A sense of security and confidentiality is essential in ensuring the participation of the foreign economic immigrants since many of them are not regularised as Spanish residents. In the selection of the participants for the focus groups we used the snowball technique, taking as our starting point residents' and foreigners' associations. Some of the informants put forward names of tourists, thereby allowing us to form groups of national second-home tourists and foreign second-home tourists. Also, in-depth interviews were used to obtain information from official representatives of local organisations. Fifteen personal interviews were carried out with the following stakeholders: local entrepreneurs (4), local politicians (5), municipal officers (2), local media professionals (1), and other local experts and key informants (3). The main objective of these interviews was to obtain information on the impacts of second-home tourism on diverse local dimensions (environment, economy, urban planning, society, culture and politics). The specific questions for each interviewee were based on his/her area of expertise, focusing on the impacts of second-home tourism in each field of knowledge. Despite the different topics discussed in each interview, all of them followed the same general structure. First, each interviewee was asked to characterize the 
present situation of his/her area of expertise. Second, they were asked to describe its evolution since the 1960s. These first blocks of questions allowed the interviewee to make a first reflection on the topic before being asked about the impacts of second-home tourism on his/her area of expertise.

From each interview and focus group we obtained a list of impacts. In the comparison of all the lists of impacts we observed redundancies or very similar impacts. In order to reduce this repeated information it was necessary to synthesise and group together some of the stakeholders' responses. Under the category Deficit in infrastructures, facilities and basic services in the second-home tourism areas we grouped together such statements as: "properties are built twelve kilometres from the centre of Dénia but they have no water and there are obviously not enough roads", and: "For years they've built near the beach but they've forgotten to widen the roads, make pavements and a lot of basic services". This subjective process in which the information of the stakeholders is interpreted and renamed implies losing part of the richness of the original information. However, as Nash (2006: 925) points out, "it is an important step in the production and development of the causal network models". Once the redundancies were eliminated, we were left with a list of 66 impacts which represent the sum of the views of the various local stakeholders.

\section{Production of causal maps}

A causal map is a sub-class of cognitive map whose aim is to display knowledge in a specific area through causality links (Weick, 1979; Miles and Huberman, 1991; Scavarda et al., 2004). The opinions, ideas and/or key issues of the problem being researched are depicted as nodes that are connected by arrows to show the direction of causality. Following Hodgkinson and Clarkson (2005), we can consider two broad types of procedures for building causal maps: indirect and direct procedures. In indirect procedures, the researcher builds the causal map based on information gathered from either primary or secondary sources (for example, textual network analysis (Diesner and Carley, 2005)). Direct procedures, however, require the direct involvement of participants in the construction of causal maps. In this case, the maps are normally created through group meetings (Ackerman and Eden, 2001; Vo, Scott and Courtney, 2005). Developed through these workshops, causal maps represent a common point of view on the issue analysed, once the different positions have been discussed. With this method, agreement among participants with differing standpoints is reached more easily than with other qualitative techniques (Albino et al., 2002). Further, the content of collective causal maps is supplied by participants using their own terminology in place of the researcher's imposed variables (Weick and Bougon, 1986: 1). Also, working with data from multiple individuals may reduce the presence of bias.

The local development of second-home tourism involves a wide range of stakeholders (Keogh, 1990). Due to this diversity of groups and interests, causal maps are best produced using a collective strategy. Experts in tourism studies defend the notion of opening up tourism planning and management to involve new social agents. These experts stress how important it is to consider the perceptions of local residents, in order to help ensure the chances of success in tourism planning and policies (Lankford, 1994; Lane, 1994; Hemmati, 2002). Authors such as Murphy (1985), Long (1993) or Jun (1994) explain how it can reduce local resistance to exogenous projects. Other authors argue that local participation produces quality information that helps to improve decision-making during the design stage of local development 
strategy options (Jamal and Getz, 1995; Brohman, 1996; Tosun and Timothy, 2003) and to identify the underlying causes of local problems (Ortiz et al., 2007). These arguments support our decision to elaborate the causal maps collectively using the information provided by the stakeholders.

In this research the stakeholders created the causal maps in the course of a two-day workshop. The number of impacts was limited to an amount that could be reasonably managed in order to build the causal maps. Of the 66 impacts identified, the stakeholders chose 16 according to their interests and values, and they were then defined as prioritised impacts (PIs) (see Table 2). The 16 PIs were grouped into four main areas (environmental, economic, social and infrastructures, and services) to make the list easier to manage in subsequent workshop phases.

Table 2. Prioritised impacts (PIs).

\begin{tabular}{|c|c|}
\hline Prioritised Impacts (PIs) & Area \\
\hline Shortage of parking spaces & \multirow{4}{*}{$\begin{array}{c}\text { Infrastructures and ser- } \\
\text { vices }\end{array}$} \\
\hline Shortage of road infrastructures & \\
\hline $\begin{array}{l}\text { Shortage of health services } \\
\end{array}$ & \\
\hline $\begin{array}{l}\text { Poor complementary provision } \\
\text { commerce and culture) }\end{array}$ & \\
\hline Increased water consumption/demand & \multirow{3}{*}{ Environment } \\
\hline Noise pollution & \\
\hline Degradation of agricultural landscape & \\
\hline High cost of living & \multirow{4}{*}{ Economy } \\
\hline Service-based economy & \\
\hline Municipal indebtedness & \\
\hline Seasonal nature of tourism & \\
\hline Population increase & \multirow{5}{*}{ Society } \\
\hline Competition for local authority resources & \\
\hline $\begin{array}{l}\text { Local authority disregard of social needs regarding shortages in in- } \\
\text { frastructures and services }\end{array}$ & \\
\hline Intercultural relations & \\
\hline Spatial segregation & \\
\hline
\end{tabular}

In this phase the local politicians and local media professionals did not take part. The local politicians were excluded due to the high probability that their participation would polarise the discussions and distort the development of the dynamic. Local media professionals were excluded because their presence could have compromised the privacy and the anonymity of the opinions expressed, thereby reducing the richness of their content.

Four work tables were organised (by topics) with 25 stakeholders. The work in each table was supervised by a facilitator, whose role consisted in ensuring that each new input to the causal map (in the 
form of nodes and arrows) had been previously deliberated and agreed by the stakeholders. Therefore, the creation of the map was the result of collaboration and discussion, and not just an aggregation of individual ideas. Also, the facilitator was the person in charge of writing down the information and drawing the map. In this way, none of the participants had more power than the rest in the construction of the causal map.

Also, this deliberative dynamic helped to ensure that the causal maps were not a mere reflection of the most obvious and general causes of the PIs. Instead, the process of deliberation allowed the causal elements with the greatest explanatory capacity to emerge (Jamal and Getz, 1995; Brohman, 1996; Tosun and Timothy, 2003, Scavarda et al., 2004; Evans, 2005).

Figure 1. PIs causal map. Degradation of agricultural landscape and ecosystem

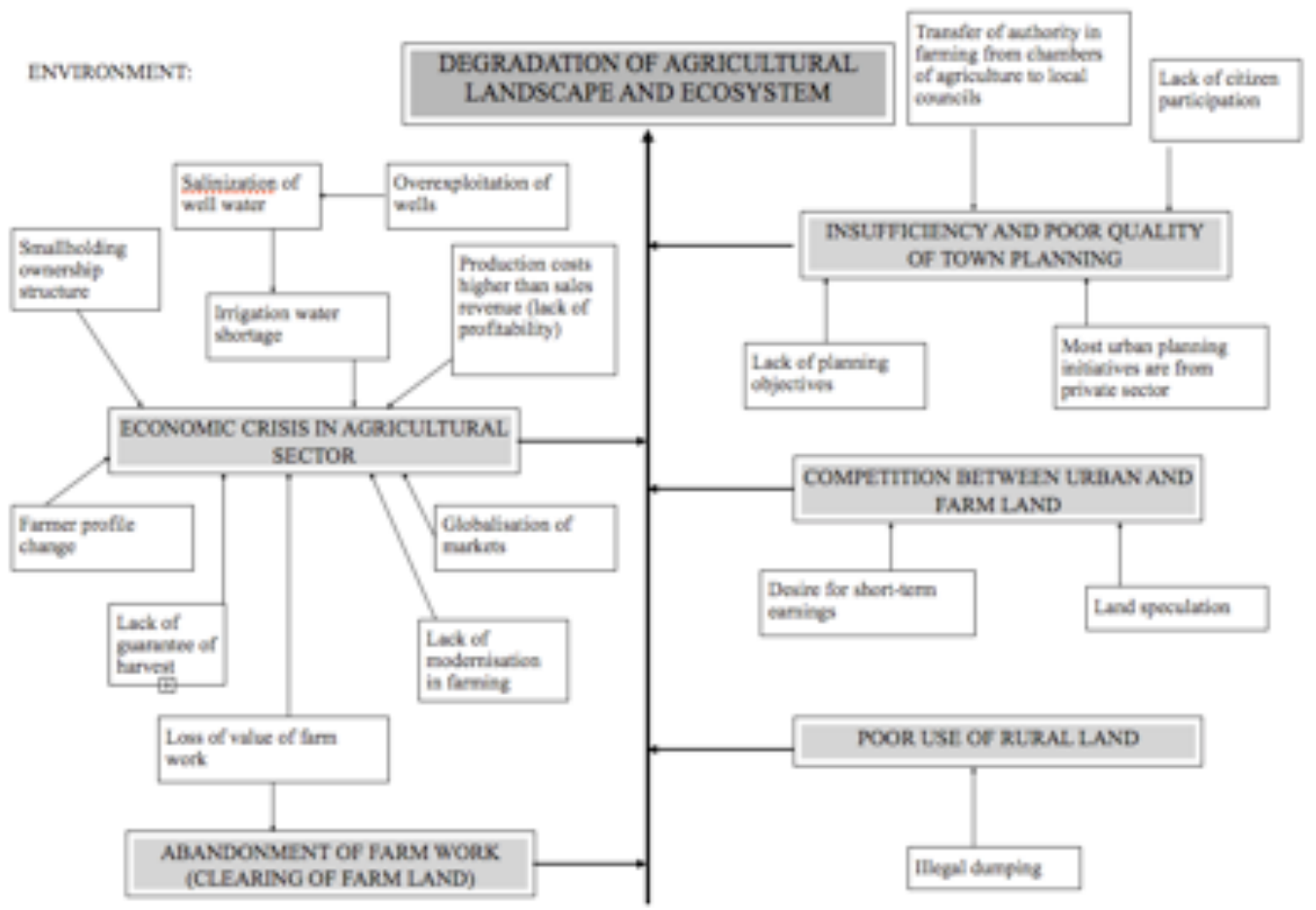

As can be seen in Figure 1, the causal map of the Degradation of agricultural landscape and ecosystem includes causes which go beyond second-home tourism (for example, "Globalisation of markets" or "Lack of guarantee of harvest"). But it also includes causes which derive to a greater or lesser extent from the existence in the town of this type of tourism. This is the case of causes such as "Abandonment of farm work (clearing of farm land)" or "Competition between urban and farm land" resulting from the production processes of urban land, processes which are much more intense in areas with second-home tourism. This wide range of causal elements for each PI is entirely logical and necessary for a proper diagnosis. Firstly, it is logical in a mature tourist town like Dénia, where the term 'second-home tourism' involves a conceptual reduction of a broad and complex reality with diffuse limits. This fact explains why the term 'tourism' does not clearly appear in the causes identified in the maps. 
Secondly, this wide range of causal elements is necessary if we wish to build a model which reflects the complexity of the causal processes giving rise to the impacts. To limit the development of the causal maps to variables exclusively related to second-home tourism would imply omitting many causes which also contribute to the generation of impacts and which allow us to develop a more comprehensive causal model. In short, the development of causal maps complements and furthers the phase of the identification of impacts. The identification of impacts phase had been characterized by the establishment of simple and direct relationships between second-home tourism and impacts. But in this later phase the causal maps allowed us to bring to our research the complexity of those causation processes in which second-home tourism takes part. Thus the most powerfully explanatory causes of the impacts are not necessarily found in the field of second-home tourism itself since, as we have already noted, second-home tourism in Dénia cannot be understood without taking local social structures into account.

However, the individual study of each causal map alone is not sufficient to determine and analyse the complex order of fluctuating consequences resulting from the local impacts of second-home tourism (Mathieson and Wall, 1982). In other words, the impacts resulting from tourism and their corresponding causes and consequences cannot be understood in isolation. On the contrary, they form an intricate system of direct and indirect relationships that needs to be analysed from a network perspective.

\section{CAUSAL MAP ANALYSIS: A PROPOSAL}

In order to outline and analyse the complex cause-and-effect processes of local impacts brought about by second-home tourism, the causal maps were analysed with UCINET and NetDraw software. This software combined and aggregated the various causal maps by linking their common elements. The resulting combination of maps yielded a larger causal map which we call from here on the Causal Network Model (Nash, 2006), composed of 197 nodes (see Figure 2). This causal network is a model which represents the complex weave of cause-effect relationships underlying the impacts of second-home tourism in Dénia. To create the Causal Network Model the nodes of the causal maps were categorised and combined in a similar way to the Identification of impacts phase. Thus, nodes present in two or more causal maps referring to the same concept but expressed differently were grouped together under a common name.

With this Causal Network Model, UCINET can systematically collate indirect relationships among the nodes. Determining and analysing the complex network of indirect relationships helps us identify the most influential nodes of the Causal Network Model. By 'most influential nodes' we understand those nodes which influence the most nodes in the network due to their connections with other nodes. It is important to bear in mind that in the definition of "most influential node" we do not consider the varying intensity of influences. In the elaboration of the causal maps only information on the existence and direction of the connections between the elements was included. In methodological terms, the causal maps used in this research, unlike those used by Woodside (2007) and Woodside, Caldwell \& AlbersMiller (2004), do not give information either on the differing intensity of the causal relationships by means of different thicknesses in the arrows, or on the positive or negative nature of the relationship. This kind of information would enrich the causal map but would complicate its elaboration, especially when 
the maps are created collaboratively. The qualification of the causal relationships as positive or negative is not necessary in this research since, by default, every causal relationship between nodes is direct (positive), that is, every arrow adds force in the causation of the effects.

Figure 2. Visual Representation of the Causal Network Model (combined causal maps)

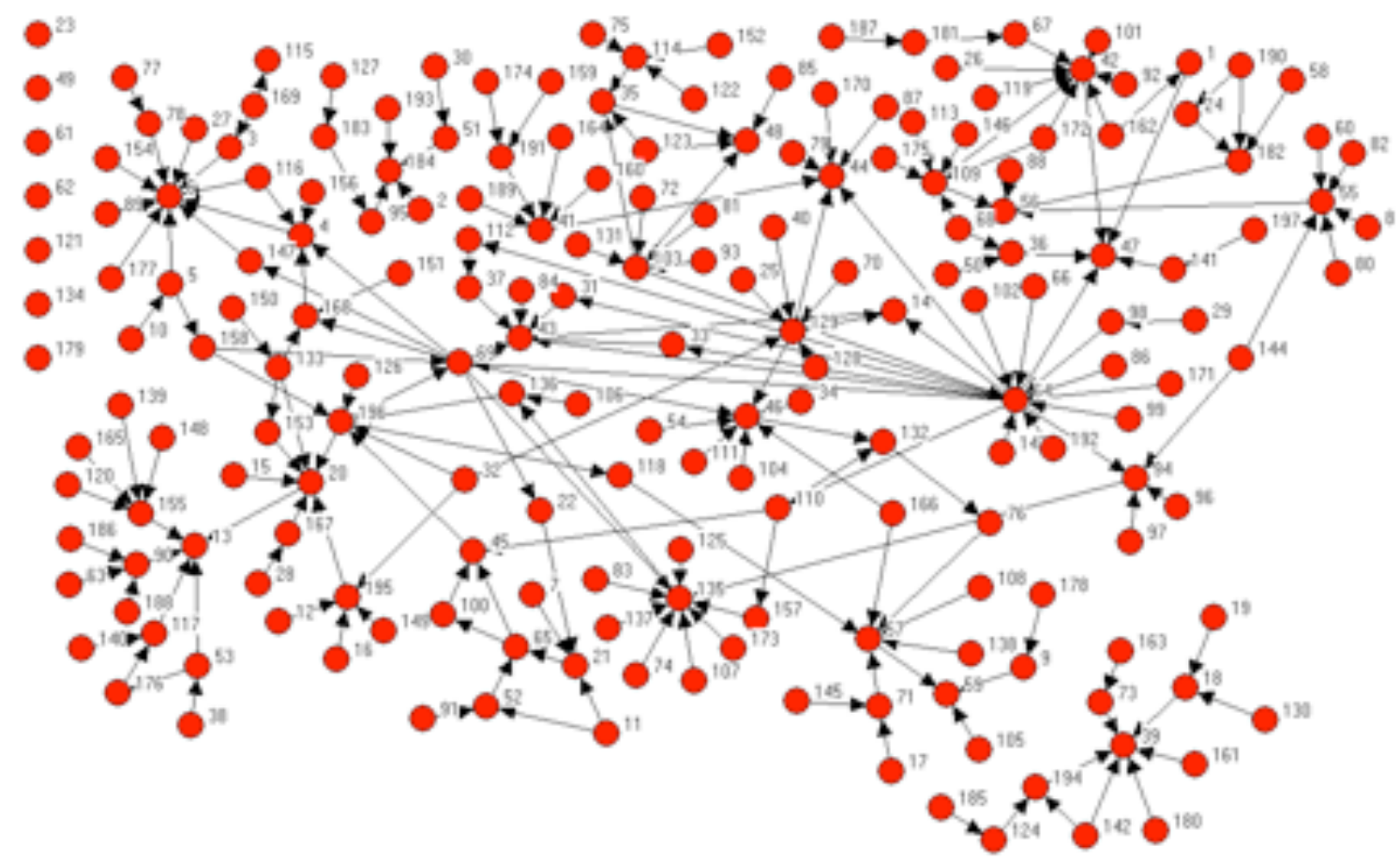

The importance of indirect relationships.

The term "indirect relationships" refers to a relationship between two nodes that is mediated by one or more other nodes. For example, in Figure 1, the relationship between Salinization of well water and Economic crisis in the agricultural sector is an indirect relationship, as it is mediated by the Irrigation water shortage node. An analysis based solely on direct relationships between nodes would be inappropriate for the following reasons:

1. It would only reflect a part of the web of inter-nodal relationships within the network.

2. Only the direct relationships of the node could be determined, i.e. the influence it has on other nodes within its immediate environment, without determining the role that it plays in the network as a whole.

3. Analysis based solely on direct relationships would be highly sensitive to the origin of the information used to create the causal map. Considering only direct relationships, if the group of stakeholders producing a particular causal chain provides a certain number of causes to explain 
the PIs, this would condition the connection of that node with the rest of the nodes in the network.

Thus, lack of systematic management of the indirect relationships among the network's nodes would mean ignoring a relevant part of the Causal Network Model. By including indirect relationships among the nodes in the analysis of the Causal Network Model, the above-mentioned limitations can be overcome, as it is possible to:

1. Manage the complex network of relationships between the set of nodes identified in the causal maps. This type of analysis allows the indirect relationships between the nodes in each causal map to be treated systematically.

2. Determine the influence of a node in the Causal Network Model (the result of combining all the causal maps) and not only its influence on those nodes directly linked to it.

3. Minimise the sensitivity of the analysis of influences to the information production process (creation of causal maps). By including in the analysis indirect relationships between nodes from different causal maps, the relationships in the network are multiplied and the connections between nodes exceed those identified in the elaboration of a causal map.

The most influential nodes in the Causal Network Model.

To identify the most influential nodes in the Causal Network Model the NA statistical indicator known as out-closeness is calculated using UCINET. The out-closeness indicator measures the capacity of each node to reach the other nodes in the network by using intermediate nodes (indirect relationships). Thus, the most influential nodes in the network are those with the highest out-closeness index, i.e. nodes which, due to their position in the network, can achieve a greater influence over other nodes. This type of analysis allows us to identify the most influential causal basis in the network. In terms of our study, identifying the most influential causal basis in the Causal Network Model for Dénia means identifying the causal origin of the PIs. This is essential when the aim is to find efficient courses of action to mitigate the PIs.

The importance of analysing indirect influences becomes clear by verifying how the most influential nodes of the Causal Network node change when indirect versus direct-only relationships appear in the analysis. For this purpose we compare the out-closeness indicator with the out-degree indicator, which measures the direct influences of each node on the rest of nodes in the network (Tables $3 \mathrm{ab})$.

Tables 3ab. Comparison between out-degree and out-closeness indicators

Table 3a (Out-degree)

Table 3b (Out-closeness) 


\begin{tabular}{|c|c|c|c|c|c|}
\hline 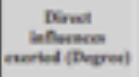 & $\begin{array}{l}\text { Netwoenk } \\
\text { lablel }\end{array}$ & Nides & Nides & $\begin{array}{l}\text { Netweek } \\
\text { lubel }\end{array}$ & 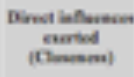 \\
\hline 10 & et & $\begin{array}{l}\text { Shortage and low qualizy of urban } \\
\text { planning }\end{array}$ & Lack of basal ausciasie porticipance & 72 & \\
\hline \multirow[t]{45}{*}{ r } & 60 & Sestonal natare of wartim & 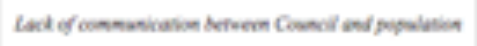 & 8: & went \\
\hline & & & 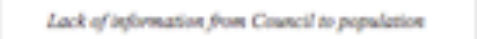 & s & \\
\hline & & & 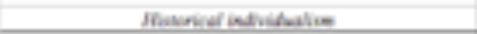 & 131 & \\
\hline & & & Lack of cation portingation & tos & SeEs \\
\hline & & & 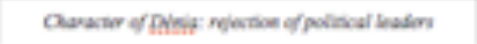 & 28 & sent \\
\hline & & & 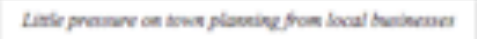 & 6 & \\
\hline & & & Iact ef polisicat conthesty & ne & \\
\hline & & & Leck af poliscel mavoriay & $\mathbf{w}$ & \\
\hline & & & Lad of plowsere efonives & to 6 & \\
\hline & & & Lack of polincal hudinty & st & esent \\
\hline & & & 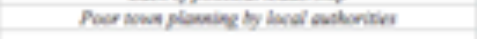 & 16 & \\
\hline & & & 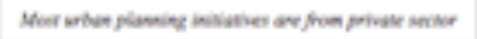 & 17 & \\
\hline & & & 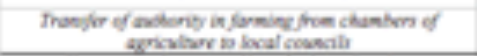 & 162 & \\
\hline & & & 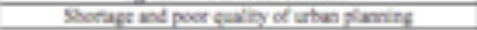 & $E 4$ & 005 \\
\hline & & & Conery & 32 & 8397 \\
\hline & & & 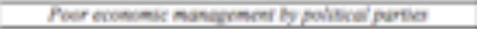 & tot & $63+5$ \\
\hline & & & 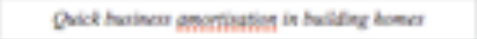 & wo & 0,57 \\
\hline & & & 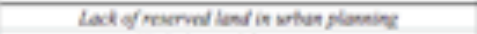 & 110 & \\
\hline & & & Met disand for porperon & 5 & \\
\hline & & & 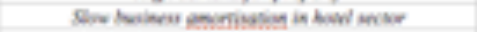 & H & \\
\hline & & & 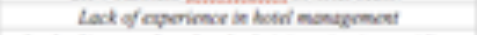 & ง. & \\
\hline & & & 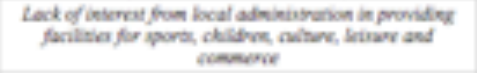 & n & 0,967 \\
\hline & & & 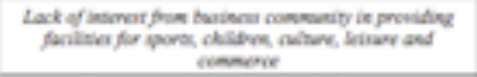 & $n$ & \\
\hline & & & 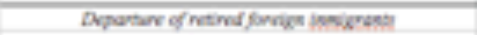 & 128 & \\
\hline & & & 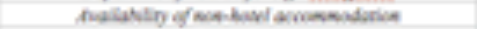 & 198 & \\
\hline & & & Inveimat focond on covernonen & 137 & \\
\hline & & & Met land prives & 7 & \\
\hline & & & 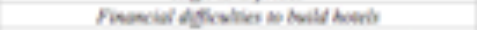 & 52 & \\
\hline & & & 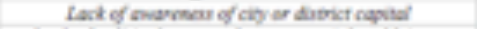 & $\mathbf{n}$ & \\
\hline & & & Lact ef political apport for coummontal and hivere & 34 & \\
\hline & & & 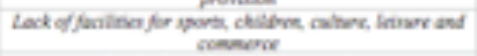 & 94 & estes \\
\hline & & & Lack of wivis isoing promotion & 106 & \\
\hline & & & 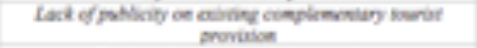 & 107 & \\
\hline & & & 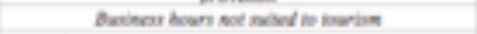 & 128 & \\
\hline & & & 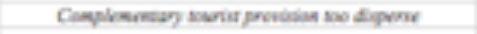 & 157 & \\
\hline & & & 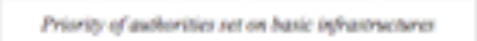 & 173 & \\
\hline & & & Seveedil nume of lourim & 6 & \\
\hline & & & 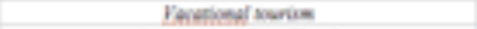 & $1 \%$ & \\
\hline & & & Lerrenfoblity of hoter & 21 & \\
\hline & & & 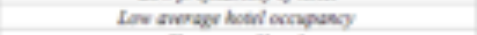 & 22 & \\
\hline & & & Shinger of herb & 45 & 84: \\
\hline & & & 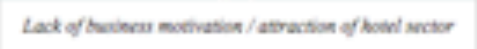 & 6 & \\
\hline & & & Lact of buser thoinew motaly & 100 & \\
\hline & & & 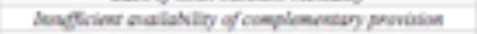 & iss & \\
\hline & & & 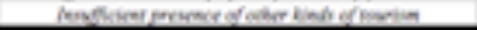 & 146 & \\
\hline
\end{tabular}

Given that the objective of this phase is to identify the most influential nodes in the Causal Network model, the previous tables only show nodes that are above the middle point of the possible range of values for the indicator in question. For example, in the out-degree indicator (Table 3a), values range from 0 to 10. Applying this screening criterion, all the nodes with a value equal to or less than 5 were discounted. Only two nodes ( $1 \%$ of the total) exceeded this cut-off point. However, by taking indirect influences (out-closeness) into account (Table 3b), 46 nodes ( $23 \%$ of the total) remain in the upper half of the range of values (which runs from 0.508 to 0.611 ). This means that analysing indirect influences increases the number of nodes in the network in a relevant position (44 nodes added to those in Table 3a) which, in a simple analysis of direct influences, would not be taken into account. This again shows that 
by factoring indirect influences into the analysis, the node position for the whole network can be determined and not just in each local network (the direct relationships of each node). Also, Table 3a shows that the node listed first, Insufficiency and poor quality of town planning, is in a lower position in Table $3 b$. Up to quite recently the most widespread thesis in tourist research about Spanish destinations (MUNRES, 1995; Vera, 1997; Mazón, 2006), also defended by official bodies, claimed this node to be the main cause of the negative local impacts of second-home tourism. Based on this idea, most proposals for the mitigation of negative impacts of second-home tourism have concentrated on creating new technical plans which would substitute the previous, failed plans. Even recent studies on the keys to failure in countries' economic development (Acemoglu and Robinson, 2012) find that there still exists a majority opinion that considers 'flaws' in economic planning to be a direct consequence of politicians' ignorance on technical questions. This argument disregards questions such as governance and interest group struggles. However, when we include indirect influences in the causal analysis (Table 3b), the most influential nodes do not now indicate planning failures but factors related to governance and the quality of democracy. Now, the nodes with the highest level of out-closeness are: Lack of local associative participation [72], Lack of communication between council and population [81], Lack of information from council to population [93] and Historical individualism [131]). In methodological terms, this change results from the fact that in some causal maps the stakeholders identified the previous nodes as causes of Insufficiency and poor quality of town planning. These stakeholders did not know what implications this would have once all the causal maps were combined, since they were unaware of the high connectedness of Insufficiency and poor quality of town planning in the Causal Network Model. The Causal Network Model is the result of the sum of partial pieces of knowledge, thus no stakeholder can know its global implications a priori. In terms of data analysis, the fact that the stakeholders have established a causal relationship between these four nodes and failures in town planning implies an important change in the nature of the origins of the impacts of second-home tourism in Dénia. When they introduce these nodes into the causal maps, the stakeholders are recognising and making explicit the political and not exclusively technical nature of town planning. The four nodes with the highest out-closeness can be interpreted as a condemnation by the stakeholders of two essential issues. On the one hand, the poor articulation of civil society in Dénia when it comes to joining forces and standing up for a larger share of participation in public affairs. On the other, the lack of effort and interest shown by the town council in opening up the decision-making process. These two processes may be feeding back into each other. The town council does not promote public participation, using as its excuse the lack of interest or willingness from civil society. And meanwhile the local population does not invest effort in forming strong social groupings involved in public affairs, arguing that the local government is cut off from society. Whatever our interpretation, what becomes clear is that the impacts of second-home tourism are not considered by the stakeholders to be unexpected failures resulting from the application of planning tools directed by the common good. This simplistic explanation would blur responsibility for the impacts at the same time as linking them to ignorance or lack of foresight. Instead, the causal maps show that the stakeholders recognise the existence of political factors underlying the exercise of town planning.

The high influence of Lack of local associative participation [72], Lack of communication between Council and population [81], Lack of information from Council to population [93] and Historical 
individualism [131] on the Causal Network Model stems from the fact that they are the best connected nodes in the network. This means that modifying the four nodes with greatest out-closeness would imply changes in Lack of participation [103]. This implies changes in Insufficiency and poor quality of town planning [64], and so on successively until we reach the PIs. That is, these four nodes are the weak point of the network, its structural Achilles' heel. This means that comprehensive and efficient action on these nodes would involve effects throughout the system. In the causation of the impacts of second-home tourism in Dénia, erroneous planning has an essential influence, but there exist deeper and systemic causes which help us understand more clearly why this destination is planned in this way. This deeper knowledge can help avoid planning "superficial" actions which may only treat the symptoms rather than the underlying causes.

\section{CONCLUSIONS}

Analysing indirect relationships in the Causal Network Model of second-home tourism in Dénia affords a sophisticated analysis of the complex cause-and-effect structure underlying the PIs identified by the stakeholders. This analysis increases our ability to systematically identify the nodes with greatest explanatory potential in this Causal Network Model. Although this methodological proposal can be applied to other tourism destinations with a different level of second home development, it takes on special relevance in the study of mature destinations for two reasons. First, Causal Network Analysis is especially useful for the identification of the causes of tourism impacts in mature destinations, where tourism is intertwined with all aspects of local reality. And second, because the collaborative construction of causal maps is a particularly valuable tool when many stakeholders are involved in the issue under discussion. This is also a common feature of mature destinations where tourism creates wide networks of interests over the years.

This method, of course, is susceptible to improvement. One could consider the possibility of including the intensity of causal relationships in the map-making, and widening the number of elements which make up the Causal Network Model. Such steps would enrich yet further the explanatory power of this tool. In terms of local planning, although this proposal does share certain limitations with other modelling methods, as they all reduce reality to a number of variables and their relationships, it provides a range of benefits due to: 1) the greater amount and higher quality of the information base resulting from the inclusion of stakeholders, and 2) the fact that it is a sophisticated information management tool that allows for deep and holistic analyses of the chosen segment of reality.

The results of the statistical analysis of the causal maps go beyond identifying the most explanatory and influential node or nodes in the network. Influence ranking provides researchers and/or planners with information that they can use to select the most profitable nodes in terms of efficiency. This knowledge allows them to act directly on these nodes would have a wider repercussion on the rest of the network than acting on less influential nodes. Nonetheless, planners may decide not to act on the most influential nodes (increasing citizen participation). Instead, they could steer intervention towards other variables which, under certain circumstances, they consider to be more accessible and/or feasible. In this 
way, planners may decide to act upon nodes which, although not ranked as the highest in terms of outcloseness, are still a good choice within the context of a particular local situation. However, failure to take any action regarding the most central, explanatory and influential nodes will reduce the effectiveness of any efforts to solve the main problems. In fact, to date, most planning decisions (supported by most of Spanish academia) taken to solve the negative local impacts of second-home tourism in Spain have focused on actions of a technical nature to address the Insufficiency and poor quality of town planning. After various decades taking action on a planning level, these negative impacts have not been solved. The results shown in this paper indicate action should be directed at improving governance in the issues concerning planning for tourism and urban development. This paper therefore shows that what at first sight might be considered a main cause to be acted upon (Insufficiency and poor quality of town planning) is in fact, in the Causal Network Model, a symptom resulting from a series of more fundamental causes. In other words, acting on these causes of a political nature would have a greater "shock wave" in the mitigation of the negative local impacts of second-home tourism.

Despite the subjectivity of the information input used to build the Causal Network Model, the results are consistent with those found in recent research, whether academic (Díez Ripollés and GómezCespedes, 2008; Naredo and Montiel, 2010), judicial (collected in the Greenpeace report Destrucción a toda costa - Destruction at Any Cost, 2010), or institutional (the Fourtou Report from the European Parliament, 2005). All of these sources reveal the corruption, lack of transparency and absence of general interest in decision-making processes on tourist and local urban development in Spain. Thus the results of this paper are in accordance with that line of research which emphasises the need to go beyond the technical aspects of planning and to consider its political aspects. The lack of information and communication between town council and civil society, as well as the scarce participation of the community in associations to monitor and defend their rights, may explain that decision-making processes in Dénia are controlled by a handful of social actors who have made use of them for their own benefit. In these circumstances, the deeper causes of the PIs are not likely to be addressed in the near future, since those who have the power to change them are, in part, also those who benefit from the current decision-making process.

\section{REFERENCES}

Acemoglu D, Robinson JA. 2012. Why nations fail. Crown Business: New York.

Ackerman F, Eden C. 2001. Contrasting Single User and Networked Group Decision Support Systems for Strategy Making. Group Decision and Negotiation 10(1): 47-66.

Albino V, Kühtz S, Scozzi B. 2002. Cognitive maps and the sustainable development in the Mediterranean region. In CIHEAM International Conference on the Relationships between Global Trades and Local Resources in the Mediterranean Region. Rabat, Morocco; 347-362.

Aledo A, Mazón T. 2005. Impacts of residential tourism and the destination life cycle theory. In Sustainable Tourism, Pineda FD, Brebbia CA (eds). Witpress: Wessex; 25-36. 
Brohman J. 1996. Popular Development: Rethinking the theory and practice of development. WileyBlackwell: Oxford.

Ciudad R. 1995. Población y desarrollo urbano de la ciudad de Denia. Espacio, Tiempo y Forma 6(8): $35-99$.

Diesner J, Carley KM. 2005. Revealing social structure from texts. In Causal Mapping for Research in Information Technology, Narayanan VK, Armstrong DJ (eds). Idea Group Publishing; 81-108.

Díez JL, Gómez-Céspedes A. 2008. La corrupción urbanística: estrategias de análisis. Revista Española de Investigación Criminológica 5(6): 41-69.

Faulkner B, Russell R. 2003. Chaos and Complexity in Tourism. In Progressing Tourism Research, Faulkner B (ed). Channel View Publications: Clevedon; 205-219.

Fernández R. 2006 El tsunami urbanizador español y mundial. Virus. Barcelona.

European Parliament. 2005. Informe sobre las alegaciones de aplicación abusiva de la LRAU y sus repercusiones para los ciudadanos europeos. http://www.europarl.europa.eu/sides/getDoc.do?pubRef=-// $\underline{\mathrm{EP} / \mathrm{NONSGML}+\mathrm{REPORT}+\mathrm{A} 6-2005-0382+0+\mathrm{DOC}+\mathrm{PDF}+\mathrm{V} 0 / / \mathrm{ES}}$

Evans JR. 2005. Total Quality: management, organization and strategy. Thompson South-Western.

García-Andreu H, Rodes J. 2004. Análisis y comparativa de cinco municipios turísticos de la Costa Blanca. In VIII Congreso Español de Sociología. A Coruña, España; 377-392.

Greenpeace. 2010. Destrucción a toda costa: http://www.greenpeace.org/espana/Global/espana/report/ other/100713-21.pdf

Hall CM, Muller DK. 2004. Tourism, Mobility and Second Homes. Channel View Publications: Clevedon. Hemmati M. 2002. Multi-stakeholder Processes for Governance and Sustainability. Earthscan: London. Hodgkinson GP, Clarkson GP. 2005. What have we learned from almost 30 years of research on causal mapping?. In Causal Mapping for Research in Information Technology, Narayanan VK, Armstrong DJ (eds). Idea Group Publishing; 46-80.

Jamal TB, Getz D. 1995. Collaboration Theory and Community Tourism Planning. Annals of Tourism Research 22(1): 186-204.

Keogh B. 1990. Public Participation in Community Tourism Planning. Annals of Tourism Research 17(3): 449-465.

Lane B. 1994. Sustainable Rural Tourism Strategies. In Rural Tourism and Sustainable Rural Development, Bramwell B, Lane B (eds). Channel View Publications: Clevedon; 102-111.

Lankford SV. 1994. Attitudes and Perceptions Toward Tourism and Rural Regional Development. Journal of Travel Research 32(3): 35-43. 
Long VH. 1993. Techniques for Socially Sustainable Tourism Development: Lessons from Mexico. In Tourism and Sustainable Development, Nelson JG, Butler RW, Wall G (eds). Department of Geography Publication University of Waterloo: Waterloo; 201-218.

Mathieson A, Wall G. 1982. Tourism economic, physical and social impacts. Longman: London.

Mazón T. 2006. Inquiring into residential tourism: The Costa Blanca case. Tourism and Hospitality Planning \& Development 3(2): 89-97.

Miles MB, Huberman AM. 1994. Qualitative Data Analysis: an expanded sourcebook. SAGE Publications: Thousand Oaks.

Morgan D, Krueger RA. 1997. The focus group Kit. SAGE Publications: Newbury Park.

Morlino L. 2003. Democrazie e democratizzazioni. Il Mulino.

MUNRES. 1995. Programa de revitalización de municipios con turismo residencial. Diputación Provincial de Alicante: Alicante.

Murphy PE. 1985. Tourism: a Community Approach. Routledge: London.

Narayanan VK, Armstrong DJ. 2005. Causal Mapping for Research in Information Technology. Idea Group Publishing.

Naredo JM, Montiel A. 2011. El modelo inmobiliario español. Icaria: Madrid.

Nash R. 2006. Casual Network Methodology. Tourism Research Applications. Annals of Tourism Research 33(4): 918-938.

Navalón MR. 1995. Planeamiento urbano y turismo residencial en los municipios litorales de Alicante. Instituto de Cultura Juan Gil-Albert: Alicante.

O’Reilly K. 2000. The British on the Costa del Sol. Routledge: London.

Ortiz G, García-Andreu H, Juan MP, Aledo A. 2007. Epistemological and ethical dilemmas of public participation on residential tourism planning. PASOS: Revista de Turismo y Patrimonio Cultural 5(3): 323-329.

Scavarda AJ, Bouzdine-Chameeva T, Meyer S, Hays JM, Hill AV. 2004. A Review of the Causal Mapping Practice and Research Literature. In Second World Conference on POM. Cancun, Mexico.

Scott J, Carrington PJ. 2011. The Sage Handbook of Social Network Analysis. SAGE Publications.

Scott N, Baggio R, Cooper C. 2008. Network Analysis and Tourism. From Theory to Practice. Channel View Publications: Clevedon.

Stroud HB. 1995. The Promise of Paradise: Recreational and Retirement Communities in the United States since 1950. Johns Hopkins University Press: London.

Tosun C, Timothy DJ. 2003. Arguments for Community Participation in the Tourism Development Process. The Journal of Tourism Studies 14(2): 2-15.

Valles MS. 2003. Técnicas cualitativas de Investigación Social. Síntesis: Madrid. 
Vera JF. 1992. Turismo y crisis agraria en el litoral alicantino. In Los mitos del turismo, Jurdao F (ed). Endymion: Madrid; 241-249.

Vera JF, Palomeque FL, Marchena M, Antón S. 1997. La dimensión territorial y ambiental del turismo. In Análisis territorial del turismo, Vera JF (ed). Ariel: Barcelona.

Vera JF, Ponce G, Ramón A, Dávila JM. 1990. Evaluación del grado de especialización turística de los municipios litorales valencianos. Revista de Investigaciones Geográficas Universidad de Alicante 8:

83-112.

Viruela R, Domingo C. 2001. Población extranjera en el País Valenciano. Arxius 5: 147-182.

Vo HV, Scott M, Courtney JF. 2005. An Empirical Comparison of Collective Causal Mapping Approaches. In Causal Mapping for Research in Information Technology, Narayanan VK, Armstrong DJ (eds). Idea Group Publishing; 142-174.

Ward JC, Reingen PH. 1990. Sociocognitive Analysis of Group Decision Making among Consumers. Journal of Consumer Research 17(3): 245-262.

Weber PS, Maning MR. 2001. Cause maps, sensemaking and planning organizational change. Journal of Applied Behavioral Science 37(2): 227-251.

Weick KE. 1979. The Social Psycology of Organizing. McGraw-Hill: New York.

Weick KE, Bougon MG. 1986. Organizations as cognitive maps: Charting ways to success and failure. In The thinking organization, Sims H, Gioia D (eds). Jossey-Bass; 102-135.

Woodside A. 2007. Training exercise in interpeting causal maps in tourism research. International Journal of Culture, Tourism and Hospitality Research 1(2): 175-179. 